\title{
Effect of Foliar Application of Specific Growth Activator on Cotton Plant
}

\author{
Saber Sh. Abd El-Gayed, O. M. M. Wassel and M. H. H. Ghourab \\ Cotton Res. Inst., Agricultural Research Center, Egypt
}

\begin{abstract}
Two field experiments were conducted during 2016 and 2017 seasons at Sids Agricultural Research Station to investigate the influence of foliar application of a commercial compound challenger (contain $20 \% \mathrm{~K}_{2} \mathrm{O}, 15 \%$ $\mathrm{N}, 5 \%, \mathrm{P}_{2} \mathrm{O}_{5}, 2.5 \% \mathrm{Zn}$ and $0.1 \% \mathrm{Fe}, \mathrm{Mn}, \mathrm{Mg}$ ) on agronomic characters and some leaves chmical components of cotton Giza 95 cultivar. Two rates of the commercial compound $(0.75 \mathrm{~g} / \mathrm{L}$ and $1.5 \mathrm{~g} / \mathrm{L})$ were used and sprayed on plants, at different stages of growth, i.e., start of squaring and start of flowering, start of squaring and peak of flowering, start of flowering and peak of flowering and start of squaring + start of flowering + peak of flowering. A randomized complete block design with four replecats was used in both seasons. The application of the commercial compound resulted in significant effect on leaves chemical composition (chlorophyll a, b and carotenoids)), growth characters (plant height, no. of fruiting branches/plant), earliness \%, yield components (No. of open bolls/plant, boll weight, seed cotton yield, and seed index), while fiber properties did not affect. The best results were obtained under application of the commercial compound at the rate of $1.5 \mathrm{~g} / \mathrm{L}$ three times, i.e., at squaring, beginning of flowering and peak of flowering, with no significant differences by using the commercial compound at the rate of $0.75 \mathrm{~g} / \mathrm{L}$ three times.
\end{abstract}

Key words: Cotton, commercial compound, NPK, growth characters, yield and its components, chlorophyll a, $\mathrm{b}$ and carotenoids and fiber properties.

\section{Introduction}

Nitrogen is one of the most important nutrients for plants. Although, nitrogen is an essential nutrient for cotton that effect on plant growth, fruiting and yield. The response of cotton plant to nitrogen application is widely varied due to cotton varieties, soil fertility and environmental conditions. Makram et al. (1994) found that nitrogen doses had little effects on plant growth, number of open bolls, boll weight, seed cotton yield/plant, lint $\%$ and seed index, while earliness \% was increased due to lower nitrogen doses.

Phosphorus is one of the major nutrients necessary for crop growth and development (Mengel and kerby, 1987). It is the second most limiting nutrient in cotton production after nitrogen. Soil phosphorus availability for crop uptake is dependent on PH, while alkalinity can adversely affect its uptake (Tisdale and Nelson, 1975). The availability of phosphorus will be improved by organic matter (Amberger, 1993).

Potassium is an important element in plant nutrition. It affects on, enzyme activation, water relations, translocation of assimilates nitrogen uptake, protein and starch synthesis. Many workers studied the effect of potassium application such as Abou El-Nour et al. (2000), El-Dosouky et al. (2001), El-Tabbakh (2001), Aneela and Asheraf (2003) and Mohsin et al. (2004) who observed positive response of cotton plants to potassium application. Sharma and Singh (2007) showed that foliar application of $2 \% \mathrm{~K}_{2} \mathrm{O}$ increased No. of open bolls/plant, boll weight and seed cotton yield.

Many authors reported the response of cotton plant to nutrient foliar application such as Abd El-Gayed et al. (2014) for nitrogen, potassium, manganese and zinc, Eleyan et al. (2014) and Yin et al. (2011) for Zinc.

The aim of this study was to evaluate the effect of commmercial compound on the quantity and quality of cotton plant grown under the conditions of clay alluvial soil of Beni-Suef Governorate.

\section{Materials and Methods}

Two field experiments were conducted, successifully on clay soil in Sids Agricultural Research Station, Agric. Res. Center, Beni-Suef Governorate, Egypt during two seasons of 2016 and 2017 to evaluate the effect of foliar application of a commercial compound on plant growth, earliness, yield and its components fiber properties and some leaves chemical composition of Egyptian cotton (Gossypium barbadense, L), cultivar Giza 95.

Soil sample were taken randomly from the experimental soil sites before sowing, to determinie some physical and chemical soil properties according to A. O. A. C. (1995), and shown in Table (1). 
Table 1. Chemical and physical properties of the studied soil before planting.

\begin{tabular}{|c|c|c|}
\hline Soil properties & 2016 & 2017 \\
\hline \multicolumn{3}{|l|}{ Physical properties: } \\
\hline \multicolumn{3}{|l|}{ Particle size distribution: } \\
\hline Clay (\%) & 53.13 & 54.26 \\
\hline Silt $(\%)$ & 27.16 & 26.12 \\
\hline Sand $(\%)$ & 19.71 & 19.62 \\
\hline Texture grade & Clay & Clay \\
\hline \multicolumn{3}{|l|}{ Chemical properties: } \\
\hline $\mathrm{pH}(1: 2.5$ soil-water suspension $)$ & 8.12 & 8.29 \\
\hline EC, Soil paste $\left(\mathrm{dS} \mathrm{m}^{-1}\right)$ & 1.01 & 1.07 \\
\hline Organic matter $(\%)$ & 1.70 & 1.73 \\
\hline Available $\mathrm{N}\left(\mathrm{ugg}^{-1}\right)$ & 22.25 & 21.19 \\
\hline Available $\mathrm{P}\left(\mathrm{ugg}^{-1}\right)$ & 14.20 & 15.07 \\
\hline Available $\mathrm{K}\left(\mathrm{ugg}^{-1}\right)$ & 165.17 & 171.33 \\
\hline
\end{tabular}

The chemical analysis of the namely Challanger is shown in Table (2) according to Agric. Com. for agric commercial compounds.

Table 2. Chemical analyses (\%) of the commercial compound are.

\begin{tabular}{ccccccc}
\hline $\mathbf{N}$ & $\mathbf{P 2 O 5}$ & $\mathbf{K 2 O}$ & $\mathbf{Z n}$ & $\mathbf{F e}$ & Mn & $\mathbf{M g}$ \\
\hline $\mathbf{1 5 \%}$ & $\mathbf{5 \%}$ & $\mathbf{2 0 \%}$ & $\mathbf{2 . 5 \%}$ & $\mathbf{0 . 1 \%}$ & $\mathbf{0 . 1 \%}$ & $\mathbf{0 . 1 \%}$ \\
\hline
\end{tabular}

The preceding crop was maize in both seasons. The experimental plot size was $12 \mathrm{~m}^{2}(4 \mathrm{~m} \times 3 \mathrm{~m})$. Each plot included 5 rows $60 \mathrm{~cm}$ apart. Phosphrous fertilizers was applied during soil preparation in the form of superphosphate $(15.5 \% \mathrm{P} 2 \mathrm{O} 5)$ at the rate of $22.5 \mathrm{~kg} / \mathrm{fed}$. Sowing date was $5^{\text {th }}$ of Apirl in both seasons. Seeds of cotton cultivar Giza 95 were sown in hills $25 \mathrm{~cm}$ apart with two plants/hill after thinning. Nitrogen fertilizer was applied in the form of ammonium nitrate $(33.5 \% \mathrm{~N})$ at the rate of 60 $\mathrm{N} /$ fed twice in two equal doses, before first irrigation and before the second irrigation. Potassium fertilizer was applied as foliar spraying of potassium sulphate at the rate of $5 \mathrm{~kg} / \mathrm{fed}$, at the beginning of flowering. The other cultural practices were carried out as recommended for convential cotton seeding in the local production district. A randomized complete block design with 4 replicates was used in both seasons.

\section{Treatments were evaluated as follows:}

1- Untreated plots as control.

2- Foliar application with $0.75 \mathrm{~g} / \mathrm{L}$ of the commercial compound twice at squaring stage and beginning of flowering.

3- Foliar application with $0.75 \mathrm{~g} / \mathrm{L}$ of the commercial compound twice, at squaring stage and peak of flowering.

4- Foliar application of $0.75 \mathrm{~g} / \mathrm{L}$ of the commercial compound twice, at beginning of flowering and peak of flowering.

5- Foliar application of $0.75 \mathrm{~g} / \mathrm{L}$ of the commercial compound three times, at squaring stage, beginning of flowering and peak of flowering.

6- Foliar application of $1.5 \mathrm{~g} / \mathrm{L}$ of the commercial compound twice, at squaring stage and beginning of flowering.
7- Foliar application of $1.5 \mathrm{~g} / \mathrm{L}$ of the commercial compound twice, at squaring stage and peak of flowering.

8- Foliar application of $1.5 \mathrm{~g} / \mathrm{L}$ of the commercial compound twice, at beginning of flowering and peak of flowering.

9- Foliar application of $1.5 \mathrm{~g} / \mathrm{L}$ of the commercial compound three times, at squaring stage, beginning of flowering and peak of flowering.

\section{Studied characters:}

After seven days from the last foliar application, leaf sample was taken from the fully maturated leaves $\left(4^{\text {th }}\right.$ leaf from the apex of the main stem) from ten plants, to determine chloroplast pigments (chlorophyll a, chlorophyll b, carotenoids) by spectro-photometer as described by A.O.A.C. (1995).

In both seasons, five representative hills (10 plants/plot) were taken as random, at harvest to study the following traits: growth characters (plant height (cm) and No of fruiting branches/plant), earliness percentage and yield components (No. of open bolls/plant, boll weight g), lint percentage, seed index (gm) and seed cotton yield (kentar/fed). At harvest and some fiber parameters (Micronair reading and pressly index) were detetrimend according to A.S.T.M., (2012).

- The statistical analysis of data was done according to Snedecor and Cochran, (1980).

\section{Results and Discussion}

\section{Leaves chemical composition:}

The data in Table (3) clearly show that application of the commercial compound had a positive effect on chlorophyll a, chlorophyll $b$, and carotenoids in both seasons comparing with control. 
Foliar application of $1.5 \mathrm{~g} / \mathrm{L}$ of the commercial compound three times, (at squaring stage, beginning of flowering and peak of flowering) seems to be the most affective on leaves chemical composition of cotton. The positive effect of the commercial compound to enhance the chlorophyll synthesis may be due to its high percentage of $\mathrm{N}, \mathrm{K}$, and $\mathrm{Mg}$. (Pandy and Sinha, 1978). Mg is one of the key elements in chlorophyll synthesis; it plays a great role as the central atom in the porphyrin structure of the chlorophyll molecule (Tucker, 1999). In addition,
$\mathrm{N}$ is essintial constituent forming chlorophyll and it has an important role in the vital process of photosynthesis. Also, the commercial compound contains $\mathrm{Mn}$ which helps in chlorophyll formation although it does not a constituent of chlorophyll through its assistant iron in chlorophyll synthesis (Lohry, 2007). Moreover, iron is required in the formation of the precursor of chlorophyll synthesis, despite that it is not constituent of chlorophyll molecule (Curie and Briat, 2003).

Table 3. Effect of foliar application of the commercial compound on leaves pigments.

\begin{tabular}{|c|c|c|c|c|c|c|}
\hline \multirow[t]{2}{*}{ Treatments characters } & \multicolumn{2}{|c|}{$\begin{array}{l}\text { Chlorophyll a } \\
\text { (mg/g dry W.) }\end{array}$} & \multicolumn{2}{|c|}{$\begin{array}{l}\text { Chlorophyll b } \\
\text { (mg/g dry W.) }\end{array}$} & \multicolumn{2}{|c|}{$\begin{array}{c}\text { Carotenoids } \\
\text { (mg/g dry W.) }\end{array}$} \\
\hline & 2016 & 2017 & 2016 & 2017 & 2016 & 2017 \\
\hline Control & 3.59 & 3.55 & 2.66 & 2.55 & 0.49 & 0.45 \\
\hline $0.75 \mathrm{~g} / \mathrm{L}$ squring + start of flowering & 3.71 & 3.60 & 2.70 & 2.61 & 0.50 & 0.46 \\
\hline $0.75 \mathrm{~g} / \mathrm{L}$ squring + peak of flowering & 3.75 & 3.63 & 2.73 & 2.63 & 0.48 & 0.47 \\
\hline $0.75 \mathrm{~g} / \mathrm{L}$ start flowering + peak of flowering & 3.77 & 3.65 & 2.75 & 2.65 & 0.47 & 0.49 \\
\hline $0.75 \mathrm{~g} / \mathrm{L}$ squring + start of flowering + peak of & 3.82 & 3.70 & 2.77 & 2.66 & 0.51 & 0.50 \\
\hline flowering & 3.85 & 3.73 & 2.79 & 2.67 & 0.50 & 0.51 \\
\hline $1.5 \mathrm{~g} / \mathrm{L}$ squring + start of flowering & 3.90 & 3.75 & 2.81 & 2.69 & 0.52 & 0.53 \\
\hline $1.5 \mathrm{~g} / \mathrm{L}$ squring + peak of flowering & 3.93 & 3.77 & 2.85 & 2.70 & 0.53 & 0.52 \\
\hline $\begin{array}{l}1.5 \mathrm{~g} / \mathrm{L} \text { start flowering + peak of flowering } \\
1.5 \mathrm{~g} / \mathrm{L} \text { squring }+ \text { start of flowering + peak of } \\
\text { flowering }\end{array}$ & 3.99 & 3.78 & 2.89 & 2.73 & 0.54 & 0.54 \\
\hline L. S. D. at 0.5 & $\mathbf{0 . 1 3}$ & 0.11 & 0.05 & 0.03 & $\mathbf{0 . 0 2}$ & 0.01 \\
\hline
\end{tabular}

\section{Growth characters:}

Results in Table (4) reveal that the tested treatments had a significant effect on growth characters (plant height at harvest and No. of fruiting branches/plant) in both seasons comparing with control. Foliar application of the commercial compound at the rate of $1.5 \mathrm{~g} / \mathrm{L}$ three times (at squaring stage, beginning of flowering and top of flowering) gave the tallest plants in both seasons, and gave the highest numbers of fruiting branches/plant, which may be due to its positive effect on several biochemical processes related to plant growth, such as stimulating the chlorophyll synthesis the commercial compound contains several macro elements which necessary to improve plant growth. Similer results were obtained by Abd El-Gayed et al (2014).

Table 4. Effect of foliar application of the commercial compound on growth characters and earliness.

\begin{tabular}{lcccccc}
\hline \multirow{2}{*}{ Treatments characters } & \multicolumn{2}{c}{ Plant height cm } & \multicolumn{2}{c}{$\begin{array}{c}\text { No. of fruiting } \\
\text { branches/plant }\end{array}$} & \multicolumn{2}{c}{ Earliness\% } \\
\cline { 2 - 7 } & 2016 & 2017 & 2016 & 2017 & 2016 & 2017 \\
\hline Control & 121.2 & 124.4 & 15.1 & 16.0 & 65.04 & 65.07 \\
0.75 g/L squring+start of flowering & 122.8 & 120.2 & 15.4 & 15.9 & 72.64 & 80.41 \\
0.75 g/L squring+peak of flowering & 123.4 & 122.8 & 15.6 & 16.4 & 72.48 & 83.43 \\
0.75 g/L start flowering+peak of flowering & 124.6 & 124.3 & 15.7 & 15.4 & 74.32 & 82.04 \\
0.75 g/L squring+ start of flowering+peak of flowering & 130.9 & 122.6 & 17.4 & 15.7 & 75.06 & 81.61 \\
1.5 g/L squring+start of flowering & 125.6 & 120.2 & 15.4 & 15.7 & 78.51 & 81.40 \\
1.5 g/L squring+peak of flowering & 127.1 & 124.3 & 15.7 & 15.5 & 75.56 & 78.53 \\
1.5 g/L start flowering+peak of flowering & 127.9 & 124.5 & 16.7 & 14.9 & 77.51 & 78.29 \\
1.5 g/L squring+ start of flowering+peak of flowering & 134.1 & 126.8 & 17.4 & 17.1 & 75.87 & 76.46 \\
\hline L. S. D. at 0.5 & 4.36 & 3.21 & 1.19 & 1.16 & 2.82 & 2.34 \\
\hline
\end{tabular}

\section{Earliness percentage:}

With regard to earliness percentage as affected with the application of the commercial compound, data presented in Table (4) showed that the tested treatments significantly affected earliness percentage in favour of application of the commercial compound two times at rate of $1.5 \mathrm{~g} / \mathrm{L}$ (at squaring stage and beginning of flowering), at the first season, while at the second season the application of the studied commercial compound two times at the rate of $0.75 \mathrm{~g} / \mathrm{L}$ (at squaring and peak off flowering) gave the highest value. The results are in line with those obtained by Eleyan et al (2014).

Yield and its components: 
Data in Tables (5 and 6) revealed that foliar application of the commercial compound three times (at squaring, beginning of flowering, and peak of flowering) increased yield parameters, No. of open bolls/plant, boll weight, seed index and seed cotton yield/fed) in both seasons, compared with control. On the other hand, lint\% did not affect by the tested treatments.

Table 5. Effect of foliar application of the commercial compound on yield components.

\begin{tabular}{|c|c|c|c|c|c|c|}
\hline \multirow{2}{*}{ Treatments characters } & \multicolumn{2}{|c|}{ No. of open bolls/plant } & \multicolumn{2}{|c|}{ Boll weight (g) } & \multicolumn{2}{|c|}{$\begin{array}{c}\text { Seed cotton yield } \\
(\mathrm{ken} / \mathrm{fed})\end{array}$} \\
\hline & 2016 & 2017 & 2016 & 2017 & 2016 & 2017 \\
\hline Control & 17.7 & 17.8 & 2.80 & 3.0 & 9.31 & 9.86 \\
\hline $0.75 \mathrm{~g} / \mathrm{L}$ squring+start of flowering & 18.0 & 19.0 & 2.96 & 2.96 & 10.06 & 10.64 \\
\hline $0.75 \mathrm{~g} / \mathrm{L}$ squring+peak of flowering & 18.3 & 20.0 & 3.00 & 3.01 & 10.14 & 10.78 \\
\hline $0.75 \mathrm{~g} / \mathrm{L}$ start flowering+peak of flowering & 18.8 & 21.2 & 3.01 & 3.09 & 10.62 & 11.10 \\
\hline $0.75 \mathrm{~g} / \mathrm{L}$ squring + start of flowering + peak of & 20.7 & 21.7 & 3.06 & 3.13 & 11.26 & 11.28 \\
\hline flowering & 19.1 & 19.9 & 3.03 & 2.86 & 10.10 & 11.26 \\
\hline $1.5 \mathrm{~g} / \mathrm{L}$ squring + start of flowering & 19.9 & 20.2 & 3.06 & 2.86 & 10.55 & 11.56 \\
\hline $1.5 \mathrm{~g} / \mathrm{L}$ squring + peak of flowering & 19.6 & 22.4 & 3.06 & 3.05 & 10.98 & 11.78 \\
\hline $\begin{array}{l}1.5 \mathrm{~g} / \mathrm{L} \text { start flowering }+ \text { peak of flowering } \\
1.5 \mathrm{~g} / \mathrm{L} \text { squring }+ \text { start of flowering }+ \text { peak of } \\
\text { flowering }\end{array}$ & 21.3 & 23.5 & 3.11 & 3.12 & 11.62 & 12.08 \\
\hline L. S. D. at 0.5 & 2.96 & 2.19 & 0.23 & 0.21 & 0.82 & 1.06 \\
\hline
\end{tabular}

Table 6. Effect of foliar application of the commercial compound on lint\%, seed index (g) and fiber properties.

Treatments characters

\section{Control}

$0.75 \mathrm{~g} / \mathrm{L}$ squring+start of flowering

$0.75 \mathrm{~g} / \mathrm{L}$ squring+peak of flowering

$0.75 \mathrm{~g} / \mathrm{L}$ start flowering+peak of flowering

$0.75 \mathrm{~g} / \mathrm{L}$ squring+ start of flowering+peak of flowering

$1.5 \mathrm{~g} / \mathrm{L}$ squring+start of flowering

$1.5 \mathrm{~g} / \mathrm{L}$ squring+peak of flowering

$1.5 \mathrm{~g} / \mathrm{L}$ start flowering+peak of flowering

$1.5 \mathrm{~g} / \mathrm{L}$ squring+ start of flowering+peak of

flowering

\begin{tabular}{cccccccc}
\multicolumn{2}{c}{ Lint \% } & \multicolumn{2}{c}{$\begin{array}{c}\text { Seed index } \\
\text { (g) }\end{array}$} & \multicolumn{2}{c}{$\begin{array}{c}\text { Micronair } \\
\text { reading }\end{array}$} & \multicolumn{2}{c}{$\begin{array}{c}\text { Pressly } \\
\text { index }\end{array}$} \\
\hline $\mathbf{2 0 1 6}$ & $\mathbf{2 0 1 7}$ & $\mathbf{2 0 1 6}$ & $\mathbf{2 0 1 7}$ & $\mathbf{2 0 1 6}$ & $\mathbf{2 0 1 7}$ & $\mathbf{2 0 1 6}$ & $\mathbf{2 0 1 7}$ \\
\hline 41.38 & 41.17 & 10.45 & 10.12 & 5.0 & 4.7 & 9.01 & 8.85 \\
41.14 & 40.25 & 10.89 & 10.51 & 4.8 & 4.5 & 9.00 & 9.22 \\
42.37 & 40.14 & 10.91 & 10.31 & 4.8 & 5.0 & 8.83 & 9.11 \\
41.69 & 40.20 & 10.07 & 10.00 & 4.6 & 4.7 & 9.17 & 9.05 \\
41.47 & 41.21 & 10.94 & 9.79 & 4.9 & 4.8 & 9.33 & 9.17 \\
41.05 & 41.00 & 10.30 & 10.45 & 4.8 & 4.9 & 8.53 & 9.14 \\
41.83 & 41.66 & 10.65 & 10.03 & 4.7 & 4.5 & 8.90 & 9.50 \\
42.33 & 41.69 & 10.72 & 10.12 & 4.9 & 4.7 & 9.20 & 8.19 \\
41.60 & 40.71 & 10.80 & 10.20 & 4.8 & 4.9 & 8.80 & 8.92
\end{tabular}

L. S. D. at 0.5

N. S. N. S.

It seemed from the obtaind results that sprying plants with the commercial compound at the rate $1.5 \mathrm{~g} / \mathrm{L}$ three times significantly produced seed cotton yield exceeded the yield of control treatment by 24.81 and $22.52 \%$ in 2016, 2017 seasons respectively.

Using the commercial compound three times at the rate of $0.75 \mathrm{~g} / \mathrm{L}$ gave better seed cotton yield as compared with using the commercial compound twice by 20.94 and $14.40 \%$ in 2016, 2017 seasons respectively.

The effect of spraying the commercial compound three times at the rate of $0.75 \mathrm{~g} / \mathrm{L}$ or at the rate of $1.5 \mathrm{~g} / \mathrm{L}$ did not significantly differ. Therefore, it can be recommended the use of rate $0.75 \mathrm{~g} / \mathrm{L}$ for the economic use.

\section{Fiber preperties:}

Results in Table (6) showed that the tested treatments had insignificant effect on fibers quality (Micronaire reading and pressly index) in both seasons.
In genieral the enhancement of the commercial compound in cotton growth and cotton productivity as well as chemical leaf cotton content is mainly due to the commercial compound contains many of vital and important elements needed for plant growth improvement, concequently increased seed cotton yield and its components.

Nitrogen affects plant growth, fruiting parameters, yield components. There is no doubt that nitrogen application enhances seedling growth, increases boll positions on the fruiting branches, provides plant leaves by chlorophyll and carotenoids, increases boll formation and cellulose precipitation in bolls (Makram et al., 1994 ). Phosphorus is one of the major nutrients, necessary for crop growth and development. It is essential for the biosynthesis of green pigments of plant, $\mathrm{P}$ is a constituent of nucliec acids, phospholipids, DNA, NADP and ATP. It is also involved in energy transfer processes in both photosynthesis and respiration. Potassium, promotes the vital processes such as photosynthetic production for plant growth $\mathrm{CO}_{2}$ and through producing ATP, 
enzyme activation, water relations, energy conversion, $\mathrm{CO} 2$ fixation, controling the bad effects of ROS by synthesis of NADPH oxidase and at the end $\mathrm{K}$ plays an important role in the translocation of storage products (Mohsin et al., 2004 and Sharma and Singh, 2007). Zinc is envolved as a cofactor for the enzymes, and it is necessary to convert tryptophan into IAA. Iron is important for chlorophyll synthesis and as a content of some respiratory enzymes. Manganese takes place in synthesis of enzymes associated with protein metabolism. Magnesium is a constituent of chlorophyll which is involved in photosynthesis processes. For the previous important modification roles of these elements that are found in the commercial compound compound, great effects on the productivity of cotton plants were evident in the present study.

\section{Conclusion}

It could be concluded to use this commercial compound as foliar spraying at rate $1.5 \mathrm{~g} / \mathrm{L}$ at squaring, beginning of flowering and peak of flowering stages to improved seed cotton productivity under Middle Egypt, Beni-suef conditions.

\section{References}

Abd-El-Gayed, S. Sh.; J. O. M. M. Wassell and M. H. H. Ghourab (2014). Response of Giza 80 to non radical nutrition during flowering stage of growth. Egypt .J. Agric. Res., 92 (1): 169-180.

Abou El-Nour, M. S. A; M. A. Saeed and M. A. Morsy (2000). Effect of potassium fertilization under two planting dates on yield, yield components and some technological and chemical properties of Giza 80 cultivar. Egypt. J. Agric. Res., 78 (3): 1219-1231.

Amberger, A. (1993). Environmentally sound, location and crop specifio application of fertiliers in a rid areas of north Africa and the near east. Proceeding of German \Egypt \Arab workshop in Cairo and Ismailia, Egypt 6-17 June, PP. -1-17.

A.O.A.C. (1995). Association of Official Agriculture Chemicals. Official Methods of Analysis. $16^{\text {th }}$ Ed. A.O.A.C. Virginia, D.C.USA.

Aneela, S. M. and A. M. E. Ashraf (2003). Effect of potash on boll characteristics and seed cotton yield in newly developed highly resistant cotton varieties .Pakistan .J.of Biol .Sci.,6 (9) 813-815.

A.S.T.M (2012). American Society for Testing and Materials. Designation (D1447-07) (D1448-97) and (D1445-67).The Society, Washington, U.S.A.

Curie, C. and J. F. Briat (2003). Iron transport and regualing in plants. Annu. Rev. Plant Biol., 54: 183-206.
Eleyan, S. E. D.; J. A. A. Abodahab; M. Amany and H.A.Rabeh (2014). Foliar application of boron and zinc effects on growth, yield and fiber properties of some Egyptian cotton cultivars (Gossypium barbadense L.). International .J.of Agric and crop Science, 7 (13): 1274- 1282.

El-Dosouky, S. A; J. Z. M.Khedr; A. L. Wanas and H. S. Ahmed (2001) . Response of the Egyptian cotton to foliar spray with some macro-nutrients (NPK) and the growth regulator paclobutrazol. Annals of Agric. Sci. Moshohor,39 (4): 2109-2125.

El-Tabbakh, S. S.(2001). Effect of sowing date and plant density on seed cotton yield and its components, earliness criteria and properties of two cotton cultivars (Gossypium spp.) to three irrigation treatments and foliar potassium application times. Alex.J.Agric.Res., 47(2):3344.

Lohry, R. (2007). Micronutrients: functions, sources and application methods, Indiana CCA Conf. Proceeding.

Makram, E. A., H. A. Abdel-ALL, K. A. Zidan and A. A. Darwish (1994). The interrelationship between planting date and each of hill spacing and nitrogen fertilization doses for the Egyptian cotton cultivar Giza 75. Annals Agric. Sci Ain Shams Univ., Cairo 39 (2):609622.

Mengel, K. and E.A. Kirkby (1987). Principles of plant Nutrition. International Potash Institute. P.O. Box, Ch. 3084, Warbling Fen-Bern, Switzerland.

Mohsin, R; H. Khan; M. J. Thir ; M. Hussain and S. Shah (2004). Effect of different combinations of NPK on growth and yield of seed cotton variety (IM-443). Sarhad. J. Agric., 20 (1): 1-4.

Pandy, S. N. and B. R. Sinha (1978). Plant Physiology. $2^{\text {nd }}$ Revised Ed. Ch 6 pp. 115.

Sharma, S. K. and Singh (2007). Yield, yield attributes and quality of cotton as influenced by foliar application of potassium .J. of Cotton Res. and Development, 21 (1): 51-54.

Snedecor, G. W. and W. G. Cochran (1980). Statistical Methods. 6th Ed. Iowa State Univ. U.S.A .pp: 225-269.

Tisdale, S.L. and W.L. Nelson (1975). Soil fertility and fertilizers. The Mach Millan Company. New York, U.S.A.

Tucker, M. R. (1999). Essential plant nutrients: Their presence in North Carolina Soils and Role in Plant Nutrition.

Yin, X. J.; O. Gwathmey; C. Main and A. Johnson (2011). Effects of sulfur application rates and foliar zinc fertilization on cotton lint yields and quality .Agronomy Journal, 103 (6): 1794-1803.Malik KA, Azam F (1985) Effect of humic acid on 


\section{تأثير الرش بمنشط النمو علي نبات القطن

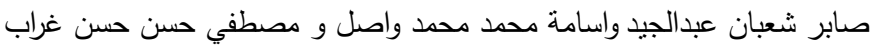 \\ معهز بحوث القطن - مركز البحوث الزراعية- مصر .}

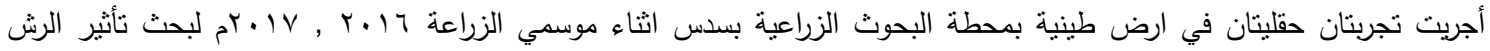

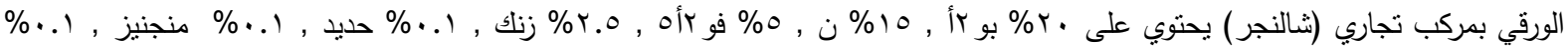
ماغنسيوم علي بعض المكونات الكيميائية لاوراق القطن , صفات النمو , التبكير , الححصول ومكوناتة وجودة تيلة القطن لصنف جيزة 90.

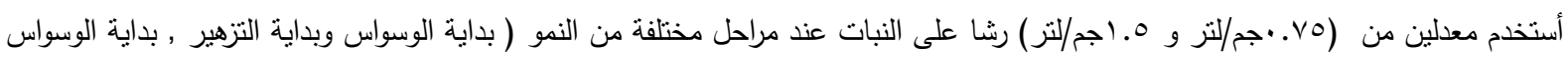

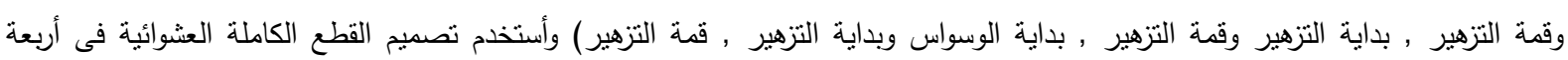
مكرات فى كلا الموسمين.

\section{ويمكن تلخيص النتائج المتحصل عليها كما يلي:}

- ادت اضافة المركب النجارى الي نبات القطن الي تأثيرات معنوية علي كل من المكونات الكيميائية للاوراق , (كلوروفيل أ , ب , كاروتينيدات) , صفات النمو (طول النبات , عدد الافرع الثمرية/النبات) , صفة التبكير ,صفات مكونات المحصول ( عدد اللوز المتقتح/نبات , وزن اللوزة (جم) , محصول القطن قنطار /فدان , كذللك معامل البذرة (جم) بينها لم يكن لـة تأثثر معنوى علي صفات التيلة (ميكرونير , بريسلى) مـع الافضلية لاستخدام المركب التجارى بمعدل ه. جم/لتر ب مرات عند بداية الوسواس وبداية التزهير وقمة التزهير , مع عدم الأختاف معنويا عن معدل

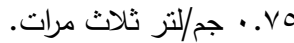
من نتائج الدراسة يمكن التوصية باستخدام المركب التجارى بمعدل 1.0 جم/لتز ثلاث مرات من بداية الوسواس وبداية التزهير وقمة التزهير لزيادة محصول القطن تحت ظروف منطقة مصر الوسطى بمحافظة بنى سويف. 